Maciej DRZONEK

DOI : $10.14746 / p p .2019 .24 .2 .9$

Uniwersytet Szczeciński

ORCID ID: https://orcid.org/0000-0002-7840-1301

\title{
Im dłużej tym „bezpartyjniej”? \\ Włodarze dużych miast w wyborach 2002-2018
}

\begin{abstract}
Abstrakt: Przedmiotem badań podjętych w artykule jest rywalizacja prezydencka w 19. polskich miastach w latach 2002-2018. Ich celem było sprawdzenie czy afiliacja partyjna częściej towarzyszyła prezydentom miast, którzy dokonywali reelekcji, czy też raczej sprzyjała alternacji władzy. Pozycję partii politycznych badano na podstawie dwóch kryteriów: liczby reelekcji prezydentów afiliowanych z partiami oraz liczby pretendentów partyjnych, którzy uzyskiwali drugi wynik po zwycięzcach. W badanych miastach odnotowano 60 przypadków reelekcji - dominowali w nich inkumbenci pozapartyjni. W 16. przypadkach alternacji władzy dominowali natomiast kandydaci partii politycznych. Na 95 przypadków elekcji lat 2002-2018 w aż 74. z nich głównymi rywalami zwycięzców byli kandydaci partii politycznych. Badanie wykazało zatem, że wielokadencyjności prezydentów sprzyja pozapartyjność, a partie polityczne odgrywają większą rolę w alternacjach władzy.
\end{abstract}

Słowa kluczowe: reelekcje prezydenta miasta, inkumbent, partie polityczne, aktor niby-bezpartyjny, personalizacja wyborów lokalnych

\section{Wprowadzenie}

$\mathbf{W}$ latach 2002-2018 odbywały się 4 kadencje prezydentów miast ${ }^{1}$. Osoby kandydujące do objęcia tych funkcji mogły startować bez żadnych limitów dotyczących ograniczenia liczby ich kadencji. W okresie tym dochodziło do stosunkowo częstych reelekcji dotychczasowych włodarzy miast na kolejne czteroletnie okresy. Możliwość dokonywania bezpośredniego wyboru przez mieszkańców, miała szczególnie istotne znaczenie w dużych miastach. O ile w małych lokalnych społecznościach partie polityczne z reguły odgrywają słabszą rolę, o tyle w miastach, zwłaszcza w tych o statusie wojewódzkim, ich pozycja na lokalnych scenach politycznych jest znacznie większa. Personalizacja elekcji prezydentów miast zapoczątkowana możliwością ich bezpośredniego wyboru w 2002 r. mogła zatem spowodować ograniczenie roli partii politycznych. Wcześniej (lata 1990-1998), kiedy radni wybierali prezydentów, to partie polityczne miały decydujące znaczenie w kreowaniu zarządów miast. W trzech pierwszych kadencjach wybór prezydentów miast był zatem konsekwencją koalicji zawieranych pomiędzy siłami politycznymi reprezentowanymi w radach, które w przeważającej mierze miały barwy partyjne. Począwszy od 2002 r. elekcje prezydentów miast w większym stopniu zostały uzależnione od ich mieszkańców.

${ }^{1}$ Również wójtów i burmistrzów, co nie jest przedmiotem niniejszych rozważań. 
Problematyka upartyjnienia i personalizacji polityki była szeroko podejmowana (Bukowski, Flis, Hess, Szymańska, 2011; Gendźwiłł, Żółtak, 2014, s. 1122-1145; Flis, Gendźwiłł, Stolicki, 2018, s. 33-64; Gendźwiłł, 2013, s. 467-486). Niekiedy personalizacja jest utożsamiana, czy wręcz synonimicznie ujmowana z prezydencjalizacją (Kowalczyk, 2014, s. 44; Peszyński, 2012, s. 204-205). W literaturze zagranicznej od dawna toczy się dyskusja na temat personalizacji i prezydencjalizacji (Poguntke, Webb, 2005, s. 1-25; Webb, Poguntke, 2013, s. 646-654; Delwit, Pilet, Reynaert, Steyvers, 2009; Reynaert, Steyvers, Delwit, Pilet, 2005; Elmelund-Præstekær, Kjaer, 2013, s. 155-167; Jacobsen, Skollevold, 2016), które nie zawsze jednak traktuje się tożsamo. Przykładowo w interesujący i przekonujący sposób dokonał rozróżnienia powyższych terminów Paolo Mancini, wedle którego prezydencjalizacja odnosi się do personalizacji ról instytucjonalnych, lideryzacja (ang. liderization) do personalizacji głównych stanowisk w ramach organizacji partyjnych, a personalizacja ,jako taka" - do skoncentrowania się wyborców na pojedynczym kandydacie podczas podejmowania decyzji wyborczej (Mancini, 2011, s. 52). Ostatnie rozumienie personalizacji wyborów w literaturze polskiej jest również obecne (Szczepański, 2016) choć prezentowane są również podejścia, w których obydwa pojęcia są traktowane nieco odmiennie (Antkowiak, Schefs, 2015, s. 120-21).

Jako, że upartyjnienie lokalnej polityki jest szczególnie widoczne w miastach, niniejsze rozważania zostaną skoncentrowane na największych polskich miastach. Ich zasadniczym celem jest sprawdzenie czy afiliacja partyjna częściej towarzyszyła prezydentom miast, którzy dokonywali reelekcji, czy też raczej sprzyjała alternacji władzy. Na wstępie można sformułować następujące hipotezy:

a) pretendent ubiegający się pierwszy raz o miejską prezydenturę ma większe szanse na sukces, startując z komitetu partii politycznej - do alternacji na stanowisku prezydenta miasta częściej doprowadzają pretendenci popierani przez partie polityczne;

b) dokonywanie reelekcji przez włodarzy miast odbywa się częściej w przypadku startu z komitetu pozapartyjnego;

c) partie polityczne najczęściej znajdują się wśród tych komitetów wyborczych, które popierają głównego rywala zwycięskiego prezydenta.

Przyjęto, że pozycję partii w elekcjach o prezydenturę miasta można ustalić na podstawie liczby afiliowanych partyjnie (formalnie lub pozaformalnie) kandydatów, którzy w latach 2002-2018 wygrywali wybory. Drugim wskaźnikiem upartyjnienia rywalizacji o miejską prezydenturę może być liczba partyjnych pretendentów do niej, którzy jej co prawda nie zdobywali, ale zarazem uzyskiwali drugi po zwycięzcy wynik (bez względu na to, czy oznaczał on wejście do drugiej tury głosowania, czy też nie).

\section{Zakres badania - dobór miast}

Do niniejszej analizy wzięto miasta na prawach powiatu, które zarazem posiadają status stolicy województwa ${ }^{2}$ oraz dodatkowo włączono do niej największy powiat grodzki, który zarazem statusu takiego nie ma (Gdynia). Ponieważ w dwóch województwach - ku-

${ }^{2}$ Status taki mają miasta, w których znajdują się siedziby wojewódzkich organów administracji rządowej (wojewoda) oraz samorządowej (marszałek i sejmik województwa). 
jawsko-pomorskie ${ }^{3}$ oraz lubuskie ${ }^{4}$ - występują po dwa miasta, w których umiejscowiono ich organy administracji rządowej lub samorządowej w sumie analizie poddano zatem 19 miast. Są to: Białystok, Bydgoszcz, Gdańsk, Gdynia, Gorzów Wlkp., Katowice, Kielce, Kraków, Lublin, Łódź, Olsztyn, Opole, Poznań, Rzeszów, Szczecin, Toruń, Warszawa, Wrocław, Zielona Góra. W tabeli 1 podano wielkości demograficzne badanych miast.

Tabela 1

Miasta poddane analizie i liczba mieszkańców, stan na 1 I 2018 r.

\begin{tabular}{|r|l|l|c|}
\hline Lp. & Woj. & \multicolumn{1}{c|}{ Miasto } & Mieszkańcy \\
\hline 1 & PDL & Białystok & 297288 \\
\hline 2 & KPM & Bydgoszcz & 352313 \\
\hline 3 & POM & Gdańsk & 464254 \\
\hline 4 & POM & Gdynia & 246306 \\
\hline 5 & LUB & Gorzów Wlkp. & 124295 \\
\hline 6 & ŚL & Katowice & 296262 \\
\hline 7 & ŚW & Kielce & 196804 \\
\hline 8 & MŁP & Kraków & 767348 \\
\hline 9 & LB & Lublin & 339850 \\
\hline 10 & ŁDZ & Łódź & 690422 \\
\hline
\end{tabular}

\begin{tabular}{|c|l|l|r||}
\hline Lp. & Woj. & \multicolumn{1}{|c|}{ Miasto } & Mieszkańcy \\
\hline 11 & WM & Olsztyn & 173070 \\
\hline 12 & OP & Opole & 128140 \\
\hline 13 & WLK & Poznań & 538633 \\
\hline 14 & PDK & Rzeszów & 189662 \\
\hline 15 & ZPM & Szczecin & 403883 \\
\hline 16 & KPM & Toruń & 202562 \\
\hline 17 & MAZ & Warszawa & 1764615 \\
\hline 18 & DLN & Wrocław & 638586 \\
\hline 19 & LUB & Zielona Góra & 139819 \\
\hline
\end{tabular}

Źródło: Opracowanie własne na podstawie danych GUS, Powierzchnia i ludność w przekroju terytorialnym w $2018 \mathrm{roku}$, https://stat.gov.pl/obszary-tematyczne/ludnosc/ludnosc/powierzchnia-i-ludnosc-w-przekrojuterytorialnym-w-2018-roku,7,15.html\#, 4 I 2019.

Jak widać, badane miasta są dość zróżnicowane pod względem demograficznym. Od największego spośród nich (Warszawa), dwa najmniejsze (Gorzów Wlkp. i Opole) są dwudziestokrotnie mniejsze. Poza nimi jeszcze cztery posiadają mniej niż 200 tys. mieszkańców (Zielona Góra, Olsztyn, Rzeszów i Kielce), a jedno - Toruń - zaledwie minimalnie ten poziom przekracza. Tym samym, łącznie aż siedem miast ze statusem wojewódzkim ma mniej mieszkańców niż największe miasto na prawach powiatu, które nie ma wojewódzkiego charakteru (Gdynia). Warto pamiętać o tych zależnościach demograficznych, gdyż status wojewódzki dotyczy w praktyce bardzo zróżnicowanych podmiotów. Zarazem łączy je jednak posiadanie tych samych, adekwatnych urzędów administracji samorządowej i rządowej, a także, co najistotniejsze z punktu widzenia podejmowanych tutaj rozważań, występowanie w nich siedzib statutowych organów kierowniczych organizacji partyjnych. Można zatem zakładać, że partie polityczne ogniskują na terenie tych miast swoją aktywność, także tę dotyczącą rywalizacji o władzę na poziomie lokalnym.

\section{Kto stoi za włodarzem, czyli istota grup chcących władzy}

Zgodnie z postanowieniami zawartymi w Kodeksie wyborczym (rozdz. II - Komitety wyborcze) formalnie, kandydata na prezydenta miasta mogą zgłaszać komitety wybor-

${ }^{3}$ Kujawsko-Pomorski Urząd Wojewódzki ma swoją siedzibę w Bydgoszczy, natomiast Urząd Marszałkowski Województwa Kujawsko-Pomorskiego umiejscowiono w Toruniu (ciekawostką jest, iż w odległości ok. $100 \mathrm{~m}$ od niego rezyduje prezydent miasta).

${ }^{4}$ W Gorzowie Wielkopolskim mieści się Lubuski Urząd Wojewódzki, a Urząd Marszałkowski Województwa Lubuskiego zlokalizowano w Zielonej Górze. 
cze, których źródłem powstania mogą być cztery kategorie podmiotów: partie polityczne, koalicje partii politycznych, stowarzyszenia i organizacje społeczne oraz wyborcy (Ustawa z dnia 5 stycznia 2011 r.). Ich formalną emanacją będą zatem, odpowiednio: komitet wyborczy partii politycznej (KWP), koalicyjny komitet wyborczy partii politycznych (KKW), komitet wyborczy organizacji (KWO) oraz komitet wyborczy wyborców (KWW) założony przez grupę co najmniej 15 osób mających prawo wybierania (Ustawa z dnia 5 stycznia 2011 r., art. 84, § 4).

Określony w prawodawstwie wyborczym formalny podział na powyższe cztery kategorie komitetów wyborczych nie zawsze odzwierciedla istotę tworzących je aktorów politycznych. Dzieje się tak dlatego, że partie polityczne, świadome popularności lokalnych, a nie partyjnych inicjatyw w środowiskach samorządowych, często uciekają się do ukrywania się pod niepartyjnie brzmiące nazwy komitetów wyborczych wyborców. Niekiedy też zawierają zakulisowe porozumienia o wsparciu komitetów lokalnych, z których list startują osoby przez nie popierane albo wręcz z nimi formalnie afiliowane. Dlatego, jak już wyrażono to wcześniej (Drzonek, 2013, s. 124-52; Drzonek, 2014), zasadne wydaje się dokonanie kategoryzacji podmiotów biorących udział w wyborach lokalnych nie tyle pod względem formalnym, lecz ze względu na faktyczną ich istotę. Można zatem wyodrębnić cztery, faktycznie występujące w rywalizacji lokalnej kategorie aktorów chcących zdobyć lub utrzymać władzę.

Do pierwszej zaliczają się aktorzy partyjni (AP), czyli partie polityczne, lub ich koalicje, które rejestrują się w ramach komitetów wyborczych partii. Nazwy takich komitetów w sposób adekwatny odzwierciedlają oficjalne nazwy partii, które go tworzą. Podmioty partyjne podejmują rywalizację wyborczą pod własnym szyldem, a zatem ani go nie ukrywają, ani też nie wykorzystują do udziału w wyborach innych, niezwiązanych z partią nazw. Ważnym atrybutem podmiotów z tej kategorii jest także ich szerokie oddziaływanie, zazwyczaj bowiem aktorzy partyjni biorą udział w wyborach w skali ogólnokrajowej, czyli w wielu lub we wszystkich okręgach wyborczych w ramach jednego, partyjnego komitetu wyborczego.

Drugą kategorią są aktorzy lokalni (AL), czyli podmioty o charakterze pozapartyjnym, które startują w wyborach samorządowych zakładając komitet wyborczy wyborców. W sensie faktycznym osoby rejestrujące taki komitet mogą reprezentować lokalną grupę aktywistów działających w ramach danej wspólnoty lokalnej, bez względu na to, jaki jest rzeczywisty cel takiego działania - zadbanie o interes społeczny ogółu (bonum commune), realizacja interesów grupy i/lub powiązanych z nią partykularnych środowisk, czy też jedno i drugie: jednoczesne dbanie o dobro wspólne oraz działanie na rzecz zaspokojenia potrzeb własnych i reprezentowanego lobby. Taką lokalną grupę aktywistów można nazwać mianem sojuszu lokalnego. Ponadto aktor lokalny może również stanowić emanację środowiska skupionego wokół lokalnego przywódcy, które w tym przypadku zostanie określone jako komitet lidera. W takim przypadku zarejestrowany komitet wyborczy wyborców będzie łatwo identyfikowalny, gdyż w jego nazwie będzie zawarte nazwisko lokalnego lidera (np. urzędującego prezydenta miasta). Istotną cechą podmiotów lokalnych jest nie tylko ich pozapartyjność, ale także węższy zakres oddziaływania - zazwyczaj (choć nieliczne wyjątki też się zdarzają) tylko w odniesieniu miejscowości, w której kandydują przedstawiciele tego podmiotu. 
Trzecia kategoria faktycznej podmiotowości wyborczej odnosi się do aktorów organizacji społecznych (AS). Są to organizacje pozarządowe i pozapartyjne, które pod własną nazwą rejestrują komitet wyborczy i w jego ramach prowadzą aktywność w rywalizacji o mandaty radnych lub o fotel prezydenta dla wyłonionego przez organizację kandydata. Aktor społeczny w ramach komitetu wyborczego organizacji oddziałuje na terenie jednej miejscowości albo ponadlokalnie na obszarze powiatu lub województwa.

Czwarta kategoria, określana tutaj jako aktor niby-bezpartyjny (AnB), ma charakter najbardziej nietypowy. O ile podmioty opisane wyżej w ramach trzech pierwszych kategorii prowadzą aktywność wyborczą $\mathrm{w}$ formalnych ramach komitetów określanych przez Kodeks wyborczy, o tyle istnienie aktorów niby-bezpartyjnych formalnie w ogóle nie zostało ujęte przez prawo wyborcze. Niedostrzeganie przez ustawodawcę występowania tej kategorii podmiotów wyborczych jest dość często wykorzystywane przez działaczy różnych partii politycznych, którzy, na potrzeby konkretnych wyborów, obawiając się negatywnych skutków startu pod szyldem własnej partii, ukrywają się za pozapartyjnie brzmiącymi nazwami rejestrowanych przez siebie komitetów wyborczych wyborców lub komitetów wyborczych organizacji.

Głównym atrybutem aktora niby-bezpartyjnego (AnB) jest zatem wystąpienie dwóch, wykluczających się założeń: komitet wyborczy jest formalnie rejestrowany jako KWW, a w praktyce tworzą go afiliowani partyjnie działacze. Niekiedy jednak niby-bezpartyjność ma bardziej wysublimowany charakter. Podmiot zarejestrowany jako KWW ma niekiedy niewidoczne związki z konkretną partią polityczną - w praktyce bowiem AnB jest bardzo często konsekwencją zawarcia formalnego lub nieformalnego sojuszu wyborczego pomiędzy jaką́s partią polityczną (lub partiami) a pozapartyjnymi aktorami na lokalnej scenie politycznej.

W tabeli 2 ukazano atrybuty oraz wzajemne zależności pomiędzy wymienionymi wyżej kategoriami aktorów wyborczych.

Tabela 2

Atrybuty faktycznych aktorów występujących w wyborach samorządowych: AP, AL, AS, AnB

\begin{tabular}{|l|c|c|c|c||}
\hline \multirow{2}{*}{\multicolumn{1}{|c|}{ Atrybuty }} & \multicolumn{4}{c|}{ Aktor (podmiot) } \\
\cline { 2 - 5 } & $\begin{array}{c}\text { partii } \\
\text { AP }\end{array}$ & $\begin{array}{c}\text { lokalny } \\
\text { AL }\end{array}$ & $\begin{array}{c}\text { spoleczny } \\
\text { AS }\end{array}$ & $\begin{array}{c}\text { niby-bezpartyjny } \\
\text { AnB }\end{array}$ \\
\hline Forma komitetu wyborczego & $\begin{array}{c}\text { KWP } \\
\text { (KKW) }\end{array}$ & KWW & KWO & KWW, KWO \\
\hline Jawne lub ukryte wsparcie partii & tak & nie & nie & tak \\
\hline $\begin{array}{l}\text { Afiliacja partyjna kandydata } \\
\text { na prezydenta }\end{array}$ & tak/nie & nie & nie & takie \\
\hline Oddziaływanie & $\begin{array}{c}\text { lokalne, regio- } \\
\text { nalne, krajowe }\end{array}$ & $\begin{array}{c}\text { lokalne, regio- } \\
\text { nalne }\end{array}$ & $\begin{array}{c}\text { lokalne, regio- } \\
\text { nalne, krajowe }\end{array}$ & $\begin{array}{c}\text { lokalne, regionalne, } \\
\text { krajowe }\end{array}$ \\
\hline
\end{tabular}

Źródło: Opracowanie własne.

\section{Wielokadencyjność, czyli reelekcje i brak alternacji}

Na zjawisko wielokadencyjności szefów egzekutyw gmin i miast szerzej zwrócono uwagę pod koniec drugiej bezpośredniej kadencji ich włodarzy. Przed wyborami 
z 2010 r. w mediach pojawiły się publikacje, w których zauważono, iż pomimo bezpośredniości wyborów wójtów, burmistrzów i prezydentów, niektórzy z nich rozpoczynali swoje władanie jeszcze w latach 90., kiedy elekcji dokonywali radni (Stelmach, 2010). Spośród sześćdziesięciu sześciu powiatów grodzkich, po trzeciej elekcji bezpośredniej z 2010 r., aż w trzydziestu miastach w fotelach prezydenckich zasiadały te same osoby co najmniej ${ }^{5}$ od 2002 roku. Po kolejnych wyborach liczba ta zmniejszyła się do 17 miast, a po elekcji z 2018 r. - do trzynastu 6 .

Nie wchodząc w szczegóły, za wielokadencyjnego prezydenta (Drzonek, 2013, s. 157-162) można uznać osobę, która dokonała co najmniej dwóch reelekcji w wyborach bezpośrednich, natomiast prezydenci o których wspomniano wyżej (wybierani zawsze od 2002 r.) będą określani mianem ,wiecznych prezydentów”.

Spoglądając na wybrane do analizy miasta, widać wyraźnie, iż w większości z nich w latach 2002-2018 dochodziło do alternacji (choć o różnej częstotliwości) osób sprawujących funkcje prezydentów miast, a jak już wyżej wspomniano, tylko w pięciu zmian w tym okresie w ogóle nie było. W tabeli 3 zebrano dane dotyczące alternacji prezydentów badanych miast po $2002 \mathrm{r}$.

Tabela 3

Wybory prezydentów badanych miast w latach 2002-2018 i ich alternacje. Za pierwszą przyjęto zawsze pierwszy wybór w sposób bezpośredni - „pierwotny wybór” w 2002 r., choć należy pamiętać, że siedem miast miało tych samych prezydentów od $1998 \mathrm{r}$.

(Białystok, Gdańsk, Gdynia, Gorzów Wlkp., Katowice, Lublin, Poznań), a w Olsztynie prezydent rozpocząl urzędowanie w trakcie kadencji 1998-2002 (2001 r.)

\begin{tabular}{||l|c|c|c|c|c||}
\hline \multicolumn{1}{|c|}{ Miasto } & $\mathbf{2 0 0 2}$ & $\mathbf{2 0 0 6}$ & $\mathbf{2 0 1 0}$ & $\mathbf{2 0 1 4}$ & $\mathbf{2 0 1 8}$ \\
\hline Białystok & $\mathrm{x}$ & $\mathrm{x}$ & - & - & - \\
\hline Bydgoszcz & $\mathrm{x}$ & - & $\mathrm{x}$ & - & - \\
\hline Gdańsk & $\mathrm{x}$ & - & - & - & - \\
\hline Gdynia & $\mathrm{x}$ & - & - & - & - \\
\hline Gorzów W. & $\mathrm{x}$ & - & - & $\mathrm{x}$ & - \\
\hline Katowice & $\mathrm{x}$ & - & - & $\mathrm{x}$ & - \\
\hline Kielce & $\mathrm{x}$ & - & - & - & $\mathrm{x}$ \\
\hline Kraków & $\mathrm{x}$ & - & - & - & - \\
\hline Lublin & $\mathrm{x}$ & $\mathrm{x}$ & $\mathrm{x}$ & - & - \\
\hline Łódź & $\mathrm{x}$ & - & $\mathrm{x}$ & - & - \\
\hline
\end{tabular}

\begin{tabular}{||l|c|c|c|c|c||}
\hline \multicolumn{1}{|c|}{ Miasto } & $\mathbf{2 0 0 2}$ & $\mathbf{2 0 0 6}$ & $\mathbf{2 0 1 0}$ & $\mathbf{2 0 1 4}$ & $\mathbf{2 0 1 8}$ \\
\hline Olsztyn & $\mathrm{x}$ & - & $\mathrm{x}$ & - & - \\
\hline Opole & $\mathrm{x}$ & - & - & $\mathrm{x}$ & - \\
\hline Poznań & $\mathrm{x}$ & - & - & $\mathrm{x}$ & - \\
\hline Rzeszów & $\mathrm{x}$ & - & - & - & - \\
\hline Szczecin & $\mathrm{x}$ & $\mathrm{x}$ & - & - & - \\
\hline Toruń & $\mathrm{x}$ & - & - & - & - \\
\hline Warszawa & $\mathrm{x}$ & $\mathrm{x}$ & - & - & $\mathrm{x}$ \\
\hline Wrocław & $\mathrm{x}$ & - & - & - & $\mathrm{x}$ \\
\hline Z. Góra & $\mathrm{x}$ & $\mathrm{x}$ & - & - & - \\
\hline
\end{tabular}

Źródło: Opracowanie własne.

$\mathrm{Z}$ powyższego zestawienia nasuwają się pewne spostrzeżenia. W większości miast raczej rzadko dochodziło do alternacji, a ich częstotliwość w badanym okresie determinowała liczbę kadencji sprawowanych na fotelu prezydenta przez tę sama osobę. Biorąc

${ }^{5}$ W kilku miastach bowiem, prezydenci sprawowali władzę od 1998 r. (np. Gdynia, Gdańsk, Sopot, Poznań), a np. w przypadku Tych - od 2000 r. Rekordzistą był już wówczas Zygmunt Frankiewicz (i nadal jest), który prezydenturę Gliwic realizuje od 1993 r. Szerzej zob. Drzonek, 2013, s. 173-359.

${ }^{6}$ Po wyborach z 2018 r. były to cztery stosunkowo małe miasta na prawach powiatu (Krosno, Legnica, Sopot, Świnoujście), cztery większe (Gliwice, Jaworzno, Tychy, Żory) oraz pięć wojewódzkich (Gdańsk, Gdynia, Kraków, Rzeszów, Toruń). Jednak po tragicznej śmierci Pawła Adamowicza w styczniu 2019 r. i wyborze jego następcy w marcu tego roku, Gdańska do tej grupy już nie można zaliczać. 
to pod uwagę można wyodrębnić badane miasta pod względem liczby reelekcji tego samego prezydenta w latach 2006-2018:

a) miasta, w których doszło do maksymalnie dwóch reelekcji (trzykrotnie wybierano tę samą osobę na prezydenta). W latach 2002-2018 wystąpiły następujące konstelacje elekcji (z dwukrotną reelekcją): 2+3 (dwukrotne zwycięstwo jednej osoby, następnie trzykrotna wygrana innej osoby: Bydgoszcz, Łódź, Olsztyn); 3+2 (sytuacja odwrotna: Gorzów Wlkp., Katowice, Opole, Poznań); 1+1+3 (dwie różne osoby wybierane na prezydenta w latach 2002 i 2006, a zwycięski pretendent z 2010 r. dokonał reelekcji w 2014 i 2018 r. - casus Lublina); 1+3+1 (w latach 2006, 2010 i 2014 r. wygrywała ta sama osoba, a w pierwszej i ostatniej elekcji - inni pretendenci - casus Warszawy);

b) miasta trzech reelekcji (w ciągu 5 elekcji bezpośrednich czterokrotnie wybierano tę samą osobę). Były możliwe dwie alternatywne konstelacje elekcji (z trzykrotną reelekcją): 1+4 (Białystok, Szczecin, Zielona Góra) lub 4+1 (Kielce, Wrocław);

c) miasta czterech reelekcji. W latach 2002-2018 w pięciu miastach (Gdańsk, Gdynia, Kraków, Rzeszów, Toruń) zawsze wybierano tę samą osobę, a więc nie dochodziło tu nigdy do alternacji na fotelu prezydenta. Tym samym, zgodnie z przyjętym wyżej kryterium przypadki te można określać mianem „miast wiecznych włodarzy”.

\section{Miasta dwóch reelekcji}

Spośród badanych miast w dwóch doszło do dwukrotnej reelekcji, choć w badanym okresie lat 2002-2018 trzech pretendentów zdobywało fotel prezydenta (formuła 1+3+1 - Warszawa, oraz 1+1+3 - Lublin). Partie polityczne miały w nich stosunkowo mocną pozycję. Widać to zwłaszcza w Warszawie, gdzie zasadnicza rywalizacja o fotel prezydenta toczyła się zawsze pomiędzy partiami. W 2002 r. wybory wygrał Lech Kaczyński reprezentujący PiS, w latach 2006-2014 wygrywała kandydatka PO Hanna Gronkiewicz-Waltz, a w 2018 reprezentujący tę partię Rafał Trzaskowski (a formalnie KKW Platforma.Nowoczesna Koalicja Obywatelska). Również drugie wyniki zawsze uzyskiwali reprezentanci partii politycznych: w 2002 r. SLD-UP (Marek Balicki), a w latach 2006-2018 - PiS (kolejno: Kazimierz Marcinkiewicz, Czesław Bielecki, Jacek Sasin, Patryk Jaki /związany z Solidarną Polską/).

Również w Lublinie wybierani prezydenci, a także niedoszli prezydenccy pretendenci byli zawsze powiązani z partiami politycznymi, przy czym dwukrotnie była to afiliacja nieformalna: w 2002 r. Andrzej Pruszkowski formalnie startował z KWW Prawo i Rodzina, lecz faktycznie był powiązany z PiS i LPR (Sidor, 2004, s. 136), a w 2018 r. prezydent Krzysztof Żuk dokonał reelekcji formalnie startując z KWW Krzysztof Żuk, choć był członkiem PO. Ponadto, o niby-bezpartyjnym charakterze jego komitetu świadczyła również obecność działaczy m.in. PO, PSL, Nowoczesnej i SLD na listach komitetu K. Żuka do rady miasta. W pozostałych lubelskich elekcjach wygrywali kandydaci oficjalnie reprezentujący PO: w 2006 r. Adam Wasilewski, a w latach 2010-2014 - K. Żuk. Przegrani pretendenci w Lublinie również zawsze reprezentowali partie polityczne: SLD (2002 - Wiesław Brodowski, 2006 - Izabela Sierakowska, /LiD/) oraz PiS (2010 - Lech Sprawka, 2014 - Grzegorz Muszyński, 2018 - Sylwester Tułajew). 
W miastach reelekcji dwukrotnej - model $2+3$ - partie miały pozycję już nieco inną. W Bydgoszczy wybierany dwukrotnie (2002 i 2006) na prezydenta Konstanty Dombrowicz startował z komitetów lokalnych (AL), podobnie w przegranej walce o reelekcję w 2010 r. oraz w 2014 r., kiedy próbował powrócić na fotel prezydenta. Jego wybierany trzykrotnie następca - Rafał Bruski - zawsze reprezentował partię polityczną (PO). Główni kontrkandydaci zwycięzcy walki o prezydenturę Bydgoszczy wywodzili się: w 2002 r. - z SLD (Roman Jasiakiewicz), 2006 r. - z komitetu pozapartyjnego (tenże - R. Jasiakiewicz), w 2018 r. z PiS (Tomasz Latos). W elekcjach z 2010 i z 2014 r. wśród przegranych pretendentów najlepsze wyniki uzyskiwał K. Dombrowicz (AL).

W Łodzi pozycja partii politycznych była zdecydowanie silniejsza. Dwukrotnie wybierany był tam Jerzy Kropiwnicki. W 2002 r. startował z komitetu lokalnego (Łódzkie Porozumienie Obywatelskie), ale z uwagi na jego powiązania z ZChN (Niewiadomska-Cudak, 2011, s. 175) w niniejszej analizie uznano go za podmiot niby-bezpartyjny (AnB). Cztery lata później wygrał on już jako oficjalny kandydat partyjny (PiS). W latach 2010-2018 prezydenturę uzyskiwała Hanna Zdanowska, która dwukrotnie reprezentowała oficjalnie partię (PO), a za trzecim razem kandydowała z KWW Hanny Zdanowskiej. Był to klasyczny przykład podmiotu niby-bezpartyjnego, ponieważ kandydatka była członkiem PO, a partia ta ją oficjalnie popierała. Przegrani pretendenci w Lodzi zawsze reprezentowali partie polityczne: SLD (2002 - Krzysztof Jagiełło, 2010 - Dariusz Joński), PO (2006 - Krzysztof Kwiatkowski) lub PiS (2014 - Joanna Kopcińska, 2018 - Waldemar Buda).

W Olsztynie elekcje prezydenckie miały odmienny charakter, gdyż zarówno ich zwycięzcy, jak i przegrani pretendenci zazwyczaj reprezentowali komitety lokalne. Tylko w 2002 r. Czesław Małkowski reprezentował SLD, a w 2006 r. jego główny rywal startował jako kandydat PiS (Jerzy Szmit). W latach 2010-2018 wybory wygrywał Piotr Grzymowicz, a jego głównym konkurentem był Czesław Małkowski - obydwaj rywalizowali wówczas w ramach własnych komitetów pozapartyjnych.

W miastach dwukrotnej reelekcji (formuła $3+2$ ) dostrzec można nieco słabszą pozycję partii politycznych - częściej zwyciężający pretendenci korzystali z komitetów pozapartyjnych $(\mathrm{AL})$ lub pozornie pozapartyjnych $(\mathrm{AnB})$. W Gorzowie urzędujący od 1998 r. Tadeusz Jędrzejczak, polityk związany z SLD, oficjalnie z tej partii startował tylko w 2002 r., a w latach 2006, 2010 i 2014 do rywalizacji przystępował w ramach komitetu niby-bezpartyjnego, przy czym w ostatnim starciu - nieskutecznie. W 2014 r. okazał się więc najsilniejszym pretendentem, a fotel prezydenta zdobył wówczas (a także w 2018 r.), Jacek Wójcicki, który w elekcjach brał udział jako kandydat pozapartyjny, choć początkowo był powiązany z Ruchami Miejskimi (Jureczko, 2016, s. 72-73). Przegrani pretendenci byli nieformalnie powiązani z partiami politycznymi (w $2002 \mathrm{r}$. Elżbieta Rafalska w ramach KWW Razem dla Gorzowa była kandydatką wspólnie popieraną przez PO i PiS, czyli startowała wówczas z komitetu typu AnB). Zazwyczaj jednak główni rywale oficjalnie reprezentowali PiS: w 2006 r. (Ireneusz Madej), w 2010 r. (ponownie E. Rafalska), a w 2018 r. - Sebastian Pieńkowski (Jańczak, Musiał-Karg, Secler, 2013, s. 216-254).

W Katowicach partie polityczne odgrywały w wyborach prezydenckich mniejszą rolę - w latach 2002-2018 prezydentem zostawał kandydat pozapartyjny, startujący zawsze z komitetu lokalnego. Elekcje lat 2002-2010 wygrywał Piotr Uszok (KWW Forum Sa- 
morządowe i Piotr Uszok), a dwie następne wskazany przez niego kontynuator - Marcin Krupa (w 2014 r. z komitetu o dokładnie tej samej nazwie, a w 2018 r. z KWW Forum Samorządowe i Marcin Krupa). Najgroźniejsi rywale P. Uszoka i M. Krupy oficjalnie reprezentowali partie: PiS (2014, Andrzej Sośnierz) lub PO (2006, Tomasz Szpyrka; 2010, Arkadiusz Godlewski; 2018, Jarosław Makowski). Natomiast w pierwszych bezpośrednich wyborach najsilniejszy konkurent P. Uszoka reprezentował podmiot niby-bezpartyjny powiązany z PO (A. Sośnierz, KWW Platforma Wyborcza Andrzeja Sośnierza).

W Opolu wybory w latach 2002-2010 trzykrotnie wygrywał Ryszard Zembaczyński $^{7}$, kandydat powiązany z PO (w 2002 r. - KWW Ryszarda Zembaczyńskiego - czyli komitet niby-bezpartyjny; potem oficjalnie z PO). Jego głównymi konkurentami byli politycy związani z SLD: Piotr Synowiec (2002, KKW SLD-UP), Andrzej Namysło (2006, LiD), Tomasz Garbowski (2010, SLD). W dwóch kolejnych elekcjach (2014 r. i 2018 r.) rywalizację prezydencką wygrywał Arkadiusz Wiśniewski startujący z własnych pozapartyjnych komitetów (KWW A. Wiśniewskiego). W pierwszym przypadku jego głównym rywalem był Marcin Ociepa reprezentujący KW Razem dla Opola (AS), a w drugim - Violetta Porowska (PiS).

Stolica Wielkopolski od 1998 r. do 2014 r. miała tego samego prezydenta - Ryszarda Grobelnego, który w 2002 r. był kandydatem PO, a następnie startując z własnych komitetów lokalnych dwukrotnie dokonywał reelekcji, a w 2014 r. odnotował porażkę w starciu z Jackiem Jaśkowiakiem (PO), który to dokonał reelekcji po czterech latach (2018 r., PO). Platforma miała także swoich przegranych pretendentów: w 2006 r. (Maria Pasło-Wiśniewska) i 2010 r. (Grzegorz Ganowicz). Z kolei w 2002 r. najlepszy wynik wśród przegrywających pretendentów uzyskał Wojciech Szczęsny-Kaczmarek (Obywatelski KWW W. Szczęsnego-Kaczmarka, prezydent Poznania w latach 1994-1998), a w 2018 r. - Tadeusz Zysk (PiS). Jak wynika z powyższych danych w elekcjach włodarza Poznania ugruntowaną, silną pozycję miała zatem PO.

\section{Miasta trzech reelekcji}

Partie polityczne odnotowywały tutaj dość zróżnicowaną pozycję. Jednoznacznie silny ich status można zaobserwować w przypadku rywalizacji prezydenckich w Białymstoku. W 2002 r. wybory wygrał tam (urzędujący od 1998 r.) Ryszard Tur, kandydat KWW Białostockie Porozumienie Prawicy. Komitet, z którego startował był klasycznym przykładem podmiotu niby-bezpartyjnego (na listach komitetu do rady kandydowali przedstawiciele różnych środowisk społecznych, ale również partii politycznych, m.in.: PO, ROP, SKL-RNP, Blok dla Polski, ZChN). Jego główny rywal, Zbigniew Puchalski również reprezentował partie polityczne (SLD-UP). Wszystkie następne elekcje (lata 2006-2018) wygrywał zawsze Tadeusz Truskolaski, który reprezentował PO (choć w 2014 r. startował z KWW T. Truskolaski, czyli komitetu niby-bezpartyjnego, a w 2018 z KKW P.NKO). Jego główny kontrkandydat zawsze reprezentował z kolei komitet wyborczy PiS (byli to kolejno: Marek Kozłowski, Dariusz Piontkowski, Jan Dobrzyński oraz Jacek Żalek, członek Porozumienia J. Gowina).

${ }^{7}$ Który będąc prezydentem nie obawiał się wzorować na rozwiązaniach zagranicznych - (zob. Bartoszewicz i in., 2017, s. 131). 
We Wrocławiu, chociaż wygrywający w latach 2002-2014 Rafał Dutkiewicz nigdy formalnie nie był kandydatem partii politycznej, to niekiedy korzystał z ich wsparcia. W latach 2002-2010 startował z KWW Rafała Dutkiewicza: w pierwszej elekcji komitet ten miał charakter niby-bezpartyjny, ponieważ posiadał wsparcie zarówno PO, jak i PiS (głównym rywalem R. Dutkiewicza była wówczas kandydatka SLD-UP Lidia Geringer d'Oedenberg). W 2006 r. obydwie partie nie wystawiły swoich pretendentów do prezydentury, choć rywalizowały z R. Dutkiewiczem o mandaty radnych miasta - pomimo nacisków, R. Dutkiewicz nie zgodził się na formalną afiliację z PO (Drzonek, 2013, s. 355). Drugi wynik osiągnął wówczas Janusz Dobrosz (LPR). Rywalizację z 2010 r. R. Dutkiewicz wygrał zdecydowanie, doprowadzając, jak zauważa Robert Alberski, do klęski PO i PiS, których kandydaci zdobyli odpowiednio 11,01\% - Sławomir Piechota i 9,99\% - Dawid Jackiewicz (Alberski, 2018, s. 21). W 2014 r. R. Dutkiewicz startował jednak w ramach KWW Rafał Dutkiewicz z Platformą (a więc klasycznego komitetu typu AnB) - w elekcji tej wygrał w II turze z Mirosławą Stachowiak-Różecką (PiS), która okazała się przegraną pretendentką także w kolejnej elekcji w 2018 r. Jej zwycięzcą został natomiast poparty przez R. Dutkiewicza Jacek Sutryk, który ostatecznie jednak był oficjalnym kandydatem KKW P.NKO, tym samym egzemplifikując dopiero w 2018 r. przypadek zdobycia wrocławskiej prezydentury przez kandydata formalnie zgłoszonego przez komitet partyjny.

Dość podobna sytuacja miała miejsce w Kielcach - tam również żaden z prezydentów nie reprezentował oficjalnie partii politycznych. We wszystkich elekcjach lat 2002-2018 brał udział Wojciech Lubawski, przegrywając tylko w ostatnim starciu z Bogdanem Wentą (KWW Projekt Świętokrzyskie). W. Lubawski startował zawsze jako kandydat KWW Porozumienie Samorządowe - Wojciech Lubawski, przy czym, trzykrotnie był to komitet niby-bezpartyjny: w 2002 r. z jego list do RM startowali m.in. kandydaci PO i PiS, w 2006 r. otrzymał poparcie tych ugrupowań (choć wystawiły one własne listy wyborcze do RM), a w latach 2014-2018 był popierany przez PiS, który zarejestrował listy do RM. A zatem tylko w 2010 r., kiedy wspierające go wcześniej ugrupowania wystawiły własnych pretendentów można zaliczyć komitet W. Lubawskiego do kategorii aktora lokalnego. W zwycięskich elekcjach W. Lubawskiego jego główny rywal zawsze reprezentował SLD (lub koalicję, w której ta partia startowała): Włodzimierz Stępień (2002), Joanna Grzela (2006), Jan Gierada (2010), Krzysztof Adamczyk (2014).

Partie polityczne odnotowywały słabszą pozycję w wyborach na prezydenta w Szczecinie (o wyborach lat 1990-2010 w Szczecinie zob. szerzej: Chrobak, 2014). W 2002 r. prezydentem został tu, dość niespodziewanie, Marian Jurczyk (KWW Niezależnego Komitetu Mariana Jurczyka), który pokonał reprezentanta SLD-UP Edmunda Runowicza. Od 2006 r. wybory wygrywał każdorazowo Piotr Krzystek (choć zawsze w II turze): w 2006 r. jako kandydat PO (zob. szerzej: Drzonek, 2008) (była to jedyna wygrana formalnie partyjnego kandydata w Szczecinie), a potem zawsze na czele własnego, lokalnego ugrupowania: KWW Piotra Krzystka Szczecin dla Pokoleń w 2010 r., Bezpartyjni KWW Piotra Krzystka w 2014 r. (o wyborach z 2014 r. w Szczecinie zob. np.: K. Kowalczyk, 2015; Drzonek, 2016, s. 99-114) oraz KWW Piotra Krzystka Bezpartyjni (2018). Trzykrotnie najsilniejszym konkurentem P. Krzystka był reprezentant dużej partii parlamentarnej: w 2006 r. - SLD (Jacek Piechota), w 2010 r. - PO (Arkadiusz Litwiński), a w 2018 r. - PiS (Bartłomiej Sochański, prezydent Szczecina lat 1994-1998). W 2014 r. 
z P. Krzystkiem przegrała starcie kandydatka podmiotu lokalnego (Małgorzata JacynaWitt, KWW M. Jacyna-Witt). Pod tym względem rywalizacje prezydenckie w Szczecinie należą do nietypowych - w kolejnych elekcjach P. Krzystek miał przeciw sobie zarówno pozapartyjną kandydatkę lokalną, jak i pretendentów trzech głównych parlamentarnych ugrupowań partyjnych. Efekty szczecińskich prezydenckich potyczek potwierdziły więc tezę o wzroście sympatii dla kandydatów spoza partii. Warto też zauważyć, iż casus P. Krzystka w rywalizacjach prezydenckich potwierdza tezę o ich personalizacji, wszak P. Krzystek odnosił sukces zarówno jako reprezentant partii politycznej, jak i w ostrej rywalizacji w stosunku do trzech $\mathrm{z}$ nich.

Schemat dotychczasowych wyborów prezydenckich w Zielonej Górze był podobny do przypadku szczecińskiego - także i tu alternacja władzy nastąpiła już 2006 r., po czym, w analizowanym okresie, już do niej nie dochodziło. W 2002 r. elekcję wygrała Bożena Ronowicz, która reprezentowała KWW Sprawiedliwa i Prawa Zielona Góra, a wiec komitet niby-bezpartyjny (wsparcie PiS). W rezultacie czterech następnych wyborów fotel prezydencki Zielonej Góry zdobywał Janusz Kubicki, początkowo (lata 2006 i 2010) jako kandydat LiD i SLD, następnie startując z KWW Janusz Kubicki (2015) ${ }^{8}$ oraz KWW Janusz Kubicki - Bezpartyjni (2018). Głównym oponentem J. Kubickiego byli kandydaci PO (w 2006 r. - Bożenna Bukiewicz, która w I turze otrzymała o 7,14\% wyższe poparcie od J. Kubickiego; w 2010 r. Elżbieta Polak) oraz powiązani z PiS (2015 - Jacek Budziński, który startował z niby-bezpartyjnego KWW Prawa i Solidarna Jacka Budzińskiego; 2018 - Piotr Barczak, jako formalny kandydat tej partii).

\section{Miasta czterech reelekcji - czyli rządy „wiecznych włodarzy”}

W Gdańsku, cztery kolejne elekcje lat 2002-2014 wygrywał Paweł Adamowicz, który każdorazowo oficjalnie reprezentował PO. Warto podkreślić, że w tych latach, wśród miast wojewódzkich to jedyny przypadek, aby wielokadencyjny prezydent zawsze kandydował jako oficjalny reprezentant jednej, tej samej partii politycznej. Co więcej, nawet wśród 66 miast na prawach powiatu casus Adamowicza był powtórzony tylko jeszcze raz'. W 2018 r. Adamowicz wystartował jednak z własnego komitetu (KWW Pawła Adamowicza Wszystko dla Gdańska) i nie tylko nie uzyskał poparcia PO, ale stanął do rywalizacji zarówno z kandydatem tej partii (Jarosław Wałęsa), jak i pretendentem PiS (Kacper Płażyński). We wcześniejszych wyborach (2002-2014) P. Adamowicz rywalizował również z pretendentami partyjnymi: w 2002 r. SLD (Marek Formela), a potem zawsze z PiS (trzykrotnie Andrzej Jaworski). Casus Gdańska to dobry przykład na to, iż silna pozycja partii nie jest dana na zawsze - jeśli dotychczasowy, partyjny inkumbent zdecyduje się na założenie pozapartyjnego komitetu,

${ }^{8}$ Z powodu zmian granic administracyjnych miasta od 1 I 2015 r. - włączenia do Z. Góry obszaru gminy Zielona Góra - wybory samorządowe w mieście (prezydent i RM) przeprowadzono 15 III $2015 \mathrm{r}$. Janusz Kubicki otrzymał poparcie od PO, która nie wystawiła własnego kandydata w rywalizacji prezydenckiej. KWW J. Kubickiego nie został mimo to uznany za niby-bezpartyjny, ponieważ komitet J. Kubickiego w wyborach do RM zdobył zdecydowanie większe poparcie niż PO.

9 W Świnoujściu prezydent Janusz Żmurkiewicz w latach 2002-2014 zawsze rywalizował jako kandydat SLD lub koalicji współtworzonych przez to ugrupowanie. 
to ma szansę na zwycięskie starcie nawet ze sprawnie działającą maszynerią dużej parlamentarnej partii politycznej.

Swoistym przypadkiem były z kolei elekcje prezydenckie w Gdyni. Urzędujący od 1998 r. Wojciech Szczurek wygrywał zawsze w pierwszej turze, zawsze startując z własnego pozapartyjnego komitetu, co więcej - zawsze również komitet ten uzyskiwał bezwzględną większość w RM. (2002 - KWW „Samorządność”; 2006-2018 - KWW Samorządność Komitet Wojciecha Szczurka). Przegranymi pretendentami względem W. Szczurka byli politycy reprezentujące różne partie polityczne: SLD-UP (2002 - Jarosław Duszewski), PiS (2006 - Zbigniew Kozak; 2014 i 2018 - Marcin Horała), PO (2010 - Wiesław Byczkowski). Pod względem słabej pozycji partii Gdynia pozostawała zatem swoistym ewenementem wśród dużych polskich miast - w żadnym innym dużym mieście partie nie zostały tak zdominowane przez silnego, pozapartyjnego inkumbenta.

Na pierwszy rzut oka dość podobna sytuacja miała miejsce w Krakowie. Tam w analizowanym okresie lat 2002-2018 na prezydenta Stołecznego Królewskiego Miasta wybierano Jacka Majchrowskiego, który początkowo był powiązany z SLD, choć startował zawsze z lokalnych komitetów. Były to: Ponadpartyjny Komitet Wyborczy Wyborców „Przyjazny Kraków” (2002), KWW Jacka Majchrowskiego (2006-2014) oraz KWW Jacka Majchrowskiego Obywatelski Kraków (2018). Należy zaznaczyć, że w pierwszym i ostatnim przypadku były to komitety niby-bezpartyjne - w 2002 r. powiązany z SLD, a w 2018 r. z KKW P.NKO. To warte podkreślenia - skoro J. Majchrowski nawet w 2018 r. startował z komitetu firmowanego jego nazwiskiem, a nie popularną wówczas nazwą „Koalicja Obywatelska”, której głównym uczestnikiem była PO, to niewątpliwie fakt ten stanowił argument potwierdzający tezę o słabszej pozycji partii w Krakowie. $\mathrm{Z}$ drugiej strony, przegrywający pretendenci do krakowskiej prezydentury wywodzili się, bądź byli powiązani z partiami politycznymi: w 2002 r. Józef Lassota (KWW „Twoje Miasto" Obywatelski Komitet Wyborczy Wyborców Józefa Lassoty, powiązany z UW), w 2006 r. Ryszard Terlecki (PiS), w 2010 r. - Stanisław Kracik (PO), w 2014 r. - Marek Lasota (PiS) oraz w 2018 r. - Małgorzata Wassermann (PiS).

Wyrazistym liderem okazał się też być, również wywodzący się ze środowiska PZPR i SLD, Tadeusz Ferenc, prezydent Rzeszowa od 2002 r. Początkowo startował on jako formalny (2002) lub nieformalny kandydat SLD (2006-2010 - KWW Tadeusza Ferenca „Rozwój Rzeszowa”) ${ }^{10}$. W latach 2014-2018 r. T. Ferenc reprezentował KW Stowarzyszenie Rozwój Rzeszowa Tadeusza Ferenca w Rzeszowie. Co prawda z listy tej też kandydowali działacze SLD, ale fakt ten świadczył o silnej pozycji personalnej T. Ferenca, a nie partii, z której się wywodził. Warte podkreślenia jest, że choć T. Ferenc nigdy nie oddał legitymacji macierzystej partii, to z czasem to nie on potrzebował poparcia partyjnego, lecz SLD korzystało z siły oddziaływania popularnego prezydenta Rzeszowa. Potwierdzeniem istotnej pozycji T. Ferenca na rzeszowskiej scenie politycznej i jego przewadze nad podmiotami partyjnymi było także i to, iż od $2010 \mathrm{r}$. - PSL, a od 2014 r. - PO nie wystawiały do rywalizacji własnych kandydatów, popierając reelekcje prezydenta Rzeszowa (Szczepański, 2015, s. 112-113). W obydwu przypadkach $\mathrm{PO}$ w wyborach do RM odnotowywała zdecydowanie niższe poparcie od ugrupowania prezydenckiego, stąd w latach 2014-2018 komitetu wyborczego T. Fe-

${ }^{10}$ Był wówczas kandydatem niby-bezpartyjnym, bo choć startował z KWW, to posiadał wówczas członkostwo w SLD, a działacze tego ugrupowania startowali z list „Rozwoju Rzeszowa”. 
renca nie można klasyfikować jako podmiotu niby-bezpartyjnego. Niewątpliwe jednak komitet T. Ferenca miał bardzo osobliwy charakter: posiadał cechy podmiotu społecznego (rejestracja w formie KW stowarzyszenia), podmiotu lokalnego (stowarzyszenie bez popularnego prezydenta Rzeszowa nie osiągnęłoby sukcesu, o czym świadczyło również wykorzystywanie w nazwie własnej komitetu wyborczego imienia i nazwiska prezydenta), a dodatkowo T. Ferenc nigdy nie oddał legitymacji partyjnej, pozostając formalnym członkiem SLD.

Konkurenci prezydenta Rzeszowa wywodzili się bądź byli popierani przez partie polityczne. W 2002 r. był to Andrzej Szlachta (KWW Rzeszowskie Porozumienie Prawicy - komitet niby-bezpartyjny), a w kolejnych wyborach reprezentanci PiS (2006 - Marian Hady; 2010 - Jerzy Cypryś; 2014 - Andrzej Szlachta; 2018 - Wojciech Buczak).

W Toruniu, w przeciwieństwie do pobliskiej Bydgoszczy, pozycja partii politycznych w rywalizacjach prezydenckich była wyraźnie słabsza. Na prezydenta miasta wybierano zawsze Michała Zaleskiego, który startował z lokalnych komitetów: KWW Czas na Gospodarza (2002), KWW Michała Zaleskiego Czas Gospodarzy (2006-2014), KWW Michała Zaleskiego (2018) ${ }^{11}$. Główni pretendenci M. Zaleskiego, z wyjątkiem wyborów z 2014 r. reprezentowali komitety powiązane nieformalnie z PO (2002 r. - KWW Obywatele Torunia; 2006 - KWW Kandydata na Prezydenta Torunia Profesora Mariana Filara - Filar dla Torunia), albo wprost PO (2010 - Waldemar Przybyszewski; 2018 - Tomasz Lenz - formalnie KKW P.NKO). W 2014 r., kiedy to M. Zaleski korzystał ze wsparcia PO główną pretendentka była Joanna Scheuring-Wielgus startująca z KWW Czas Mieszkańców - Porozumienie Ruchów Miejskich.

\section{Wnioski}

Analiza wyników wszystkich dotychczasowych bezpośrednich elekcji prezydentów miast w sumie pozwoliła wyodrębnić 95. przypadków: dotychczas wybory te odbywały się bowiem pięciokrotnie, a badaniu poddano 19 miast. W 60. przypadkach odnotowano reelekcje, a w 35. - dokonały się zmiany na stanowiskach prezydentów miast. Biorąc jednakże pod uwagę poczynione na początku analizy założenie, iż każdą z 19 elekcji z 2002 r. uznano za pierwotny wybór, to w rzeczywistości alternacje mogły zachodzić w latach 2006-2018. Do alternacji doszło zatem w 16. przypadkach.

Podczas pierwszej, pierwotnej elekcji bezpośredniej w 2002 r. pretendenci formalnie afiliowani przez partie polityczne wygrywali w 6 . przypadkach, przy czym dwóch reprezentowało PO, jeden - PiS, a trzech - SLD. Aż ośmiu zwycięskich kandydatów reprezentowało podmioty o charakterze niby-bezpartyjnym. Tylko w 5. miastach wygrywali wówczas kandydaci startujący z lokalnych komitetów.

Dzięki powyższej analizie, można dostrzec jeszcze większą przewagę partii politycznych w 16. przypadkach alternacji władzy lat 2006-2018: dziesięciokrotnie fotele prezydenckie uzyskiwali politycy PO, w jednym przypadku sukces odnotował pretendent reprezentujący SLD, a w pięciu - kandydaci komitetów lokalnych.

${ }^{11}$ Ponieważ w 2014 r. PO nie wystawiła własnego kandydata na prezydenta, a w wyborach do rady osiągnęła lepszy rezultat niż komitet M. Zaleskiego, w świetle przyjętych założeń komitet prezydenta można uznać za aktora niby-bezpartyjnego 
Pierwsza hipoteza sformułowana na początku powyższych rozważań została zatem potwierdzona - formalna afiliacja komitetów wyborczych z partiami politycznymi (a także nieformalne powiązania prezydenckich pretendentów w ramach AnB) częściej przynosiły sukces zarówno podczas elekcji pierwotnej (2002 r.) jak i - zwłaszcza - podczas alternacji władzy w latach 2006-2018. Wyraźnie widać, że alternacje zachodziły rzadko, ale jeśli już do nich dochodziło, to zdecydowanie częściej przy udziale komitetów partii politycznych, aniżeli pretendentów reprezentujących komitety lokalne.

Druga hipoteza - o słabszej pozycji partii w kolejnych reelekcjach również została potwierdzona w toku analizy. Szczegółowo pozycję partii w poszczególnych kategoriach badanych miast zaprezentowano w tabelach 4, 5 i 6.

Tabela 4

Przypadki ponownego wyboru prezydentów w miastach dwóch reelekcji (Bydgoszcz, Gorzów Wlkp., Katowice, Lublin, Lódź, Olsztyn, Opole, Poznań, Warszawa)

\begin{tabular}{||l|c|c|c|c|c|c|}
\hline \hline \multicolumn{7}{|c|}{ Komitety prezydenckie } \\
\hline \multicolumn{1}{|c|}{ Typ } & $\mathbf{2 0 0 2}$ & $\mathbf{2 0 0 6}$ & $\mathbf{2 0 1 0}$ & $\mathbf{2 0 1 4}$ & $\mathbf{2 0 1 8}$ & razem \\
\hline PO & $\mathrm{x}$ & 1 & 2 & 4 & 2 & 9 \\
\hline PiS & $\mathrm{x}$ & 1 & & & & 1 \\
\hline SLD & $\mathrm{x}$ & & & & & 0 \\
\hline AnB & $\mathrm{x}$ & 1 & 1 & 0 & 2 & 4 \\
\hline AL & $\mathrm{x}$ & 4 & 2 & 1 & 4 & 11 \\
\hline
\end{tabular}

Źródło: Opracowanie własne.

Tabela 5

Przypadki ponownego wyboru prezydentów $\mathrm{w}$ miastach trzech reelekcji (Białystok, Kielce, Szczecin, Wrocław, Zielona Góra)

\begin{tabular}{||l|c|c|c|c|c|c|}
\hline \multicolumn{7}{|c|}{ Komitety prezydenckie } \\
\hline \multicolumn{1}{|c|}{ Typ } & $\mathbf{2 0 0 2}$ & $\mathbf{2 0 0 6}$ & $\mathbf{2 0 1 0}$ & $\mathbf{2 0 1 4}$ & $\mathbf{2 0 1 8}$ & razem \\
\hline PO & $\mathrm{x}$ & & 1 & & 1 & 2 \\
\hline PiS & $\mathrm{x}$ & & & & & 0 \\
\hline SLD & $\mathrm{x}$ & & 1 & & & 1 \\
\hline AnB & $\mathrm{x}$ & 1 & & 3 & & 4 \\
\hline AL & $\mathrm{x}$ & 1 & 3 & 2 & 2 & 8 \\
\hline
\end{tabular}

Źródło: Opracowanie własne.

Tabela 6

Przypadki ponownego wyboru prezydentów w miastach czterech reelekcji (Gdańsk, Gdynia, Kraków, Rzeszów, Toruń)

\begin{tabular}{||l|c|c|c|c|c|c|}
\hline \multicolumn{7}{|c|}{ Komitety prezydenckie } \\
\hline \multicolumn{1}{|c|}{ Typ } & $\mathbf{2 0 0 2}$ & $\mathbf{2 0 0 6}$ & $\mathbf{2 0 1 0}$ & $\mathbf{2 0 1 4}$ & $\mathbf{2 0 1 8}$ & razem \\
\hline PO & $\mathrm{x}$ & 1 & 1 & 1 & & 3 \\
\hline PiS & $\mathrm{x}$ & & & & & 0 \\
\hline SLD & $\mathrm{x}$ & & & & & 0 \\
\hline AnB & $\mathrm{x}$ & 1 & 1 & 1 & 1 & 4 \\
\hline AL & $\mathrm{x}$ & 3 & 3 & 3 & 4 & 13 \\
\hline
\end{tabular}

Źródło: Opracowanie własne. 
$\mathrm{Na}$ 60. przypadków reelekcji w czterech kolejnych wyborach lat 2006, 2010, 2014 i 2018 ponad połowa - 32 - dotyczyła inkumbentów reprezentujących pozapartyjne komitety lokalne (AL). Natomiast łącznie tylko w 16. przypadkach reelekcji dokonywali prezydenci oficjalnie afiliowani z komitetami partyjnymi: najwięcej miała PO (14), a SLD i PiS zaledwie po jednym. W dwunastu przypadkach rywalizację o reelekcję z sukcesem kończyli prezydenci nieformalnie powiązani z partiami politycznymi (AnB). Fakt ten potwierdza słabszą pozycję partii w walce o utrzymanie foteli włodarzy miast - gdyby bowiem prezydenci oficjalnie reprezentujący partie cieszyli się większym poparciem, to partie polityczne nie uciekałyby się przecież do stosowania rozwiązań nibybezpartyjnych.

Z zestawienia w tabeli 4 wynika jednak, iż w miastach dwukrotnej reelekcji można zauważyć częstsze ich dokonywanie przez inkumbentów afiliowanych partyjnie, a w miastach trzy- i czterokrotnej reelekcji wyraźnie dostrzega się rzadsze przypadki partyjnych inkumbentów (tabele 5 i 6). Tym samym warte podkreślenia jest spostrzeżenie, że im dłużej inkumbent sprawuje władzę, tym bardziej prawdopodobne jest osłabienie pozycji partii politycznych na lokalnej scenie politycznej.

Potwierdzona została także hipoteza trzecia - w przeważającej mierze wśród głównych rywali zwycięskich pretendentów do foteli prezydenckich byli kandydaci reprezentujący partie polityczne. Spośród 95 przypadków elekcyjnych było ich aż 74. Szczegóły zebrano w tabeli 7 .

Tabela 7

Komitety głównych rywali w latach 2002-2018

w analizowanych miastach

- podział na poszczególne typy komitetów

\begin{tabular}{|l|c|}
\hline \multicolumn{1}{|c|}{ Typ komitetu rywala } & Liczba \\
\hline PO & 14 \\
\hline PiS & 39 \\
\hline SLD & 20 \\
\hline LPR & $\mathbf{1}$ \\
\hline AnB & 9 \\
\hline AL & 12 \\
\hline Razem & $\mathbf{9 5}$ \\
\hline
\end{tabular}

Źródło: Opracowanie własne.

Z powyższego zestawienia wynika, że najczęściej swoich przegranych pretendentów posiadał PiS, a w dalszej kolejności - SLD i PO.

Reasumując, partie polityczne charakteryzują się słabszą pozycją w sytuacji reelekcji, im więcej kadencji ma za sobą włodarz miasta, tym rzadziej korzysta z zaplecza partyjnego - wśród pięciu miast, w których prezydentem jest ta sama osoba od $2002 \mathrm{r}$. w 2018 r. żaden formalnie nie kandydował z komitetu partii politycznej.

W badanych miastach pozapartyjność sprzyjała zatem dłuższym rządom. Badanie pokazało również, że wraz z dokonywaniem kolejnych reelekcji inkumbenci niwelowali lub ograniczali swoje związki z partiami politycznymi. „Partyjność” sprzyjała jednak alternacji władzy - w dwóch miastach, w których najczęściej do nich dochodziło (Lublin, 
Warszawa) wygrywający po raz pierwszy pretendenci wywodzili się z partii politycznej (PO). Dzięki powyższej analizie można również dostrzec, że w obrębie partii politycznych jedna z nich - PO - dominuje w liczbie afiliowanych z nią zwycięskich prezydentów, a druga - PiS - prym wiodła w liczbie posiadanych najsilniejszych pretendentów przegrywających zazwyczaj z inkumbentami.

Po przeprowadzeniu analizy reelekcji w miastach wojewódzkich uzasadnione wydaje się generalne spostrzeżenie: skoro partie posiadają ograniczoną zdolność dokonywania reelekcji, to dla większości wyborców, w rywalizacji o prezydentury miast, ich personalizacja jest zdecydowanie bardziej atrakcyjna od afiliacji partyjnych prezydenckich pretendentów. Politycy w dużych polskich miastach zdają się dobrze wyczuwać te preferencje ich mieszkańców.

\section{Bibliografia}

Alberski R. (2018), Partycypacja w metropolii - przypadek Wrocławia, w: M. Drzonek, Polityka w mieście. Współdecydowanie, WNUS, Szczecin.

Antkowiak P., Schefs Ł. (2015), Teoria i praktyka przywództwa politycznego. Na przykładzie bezpośrednich wyborów wójta, burmistrza i prezydenta miasta, Wydawnictwo Naukowe WPID UAM, Poznań.

Bartoszewicz M. i in. (2017), Miasta Dolnego Śląska i Opolszczyzny po reformie administracji publicznej z 1998 r. Próba bilansu, w: W cieniu statusu. Miasta Dolnego Śląska i Opolszczyzny po reformie administracji publicznej z 1998 r., red. A. Wołek, Ośrodek Myśli Politycznej, Kraków.

Bukowski M., Flis J., Hess A., Szymańska A. (2011), Opcja czy osoba? Upartyjnienie versus personalizacja w wyborach samorządowych, WUJ, Kraków.

Chrobak P. (2014), Wybory samorzadowe w Szczecinie na tle Pomorza Zachodniego w latach 19902010. Preferencje wyborcze mieszkańców regionu zachodniopomorskiego, WHUS - „Dokument", Szczecin.

Delwit P., Pilet J.-B., Reynaert H., Steyvers K. (red.) (2009), Local political leadership in Europe: town chief, city boss or loco president?, Vanden Broele, Brugge.

Drzonek M. (2008), AntyJurczyk wygrywa. Uwagi o wyborach samorzadowych w Szczecinie w $2006 r$., w: Władza i polityka lokalna. Polskie wybory samorząowe 2006 r., red. A. Wołek, Ośrodek Myśli Politycznej, Kraków.

Drzonek M. (2013), Reelekcje prezydentów miast w wyborach bezpośrednich w Polsce, Dante, Kraków.

Drzonek M. (2016), Preferencje polityczne wśród kandydatów na radnych. Przypadek wyborów w Szczecinie w 2014 r., w: Polityka Lokalnie. Kampania $i$ wybory samorzadowe 2014, red. M. Drzonek, K. Oświecimski, A. Wołek, Wydawnictwo WAM, Akademia Ignatianum w Krakowie, Kraków.

Drzonek M. (red.) (2014), Partyjnie czy bezpartyjnie? Szkice o zdobywanie władzy lokalnej, WNUS, Szczecin.

Elmelund-Præstekær C., Kjaer U. (2013), Presidentialisation of parliamentary systems? Frontrunner concentration in Danish local elections, "Representation", $\mathrm{nr} 2$ (49).

Flis J., Gendźwiłł A., Stolicki D. (2018), Rywale włodarzy. Doświadczenia i szanse samorządowych pretendentów, „e-Politikon”, nr 26.

Gendźwiłł A. (2013), Why do Poles (still) Dislike Political Parties? Some Survey Insights into AntiParty Attitudes in Poland, 1995-2011, „Polish Sociological Review”, nr 4 (184). 
Gendźwiłł A., Żółtak T. (2014), Why Do Non-partisans Challenge Parties in Local Politics?, „EuropeAsia Studies", vol. 66.

Jacobsen D. I., Skollevold A. S. (2016), Presidentialisation on the executive arena at the local level? The case of Norway 1992-2012, „Zarządzanie Publiczne”, nr 1 (35).

Jańczak J., Musiał-Karg M., Secler B. (2013), Wybory samorzadowe na Ziemi Lubuskiej, Pomorzu $i$ Wielkopolsce, Adam Marszałek, Torun.

Jureczko J. (2016), Analiza kampanii wyborczej prezydenta Gorzowa Wlkp. Jacka Wójcickiego, w: Polityka Lokalnie. Kampania i wybory samorzadowe 2014, red. M. Drzonek, K. Oświecimski, A. Wołek, Wydawnictwo WAM, Akademia Ignatianum w Krakowie, Kraków.

Kowalczyk K. (2014), Prezydencjalizacja wyborów samorzadowych w Szczecinie w 2010 r., w: Partyjnie czy bezpartyjnie? Szkice o zdobywanie władzy lokalnej, red. M. Drzonek, WNUS, Szczecin.

Kowalczyk K. (2015), Wybory samorzadowe w 2014 r. w Szczecinie, Soft Vision, Szczecin.

Mancini P. (2011), Leader, president, person: Lexical ambiguities and interpretive implications, „European Journal of Communication", nr 26.

Niewiadomska-Cudak M. (2011), Wybory samorzadowe w Łodzi w latach 1990-2006, Adam Marszałek, Toruń.

Peszyński W. (2012), Zjawisko prezydencjalizacji kampanii samorządowych. Przykład wyborów 2010 roku w województwie kujawsko-pomorskim, w: Media i marketing polityczny, red. M. Jeziński, W. Peszyński, A. Seklecka, Toruń.

Poguntke T., Webb P. (2005), The presidentialization of politics in democratic societies: A framework for analysis, w: The presidentialization of politics: a comparative study of modern democracies, red. T. Poguntke, P. Webb, Oxford University Press, Oxford.

Reynaert H., Steyvers K., Delwit P., Pilet J.-B. (red.) (2005), Revolution or renovation? Reforming local politics in Europe, Vanden Broele, Brugge.

Sidor M. (2004), Bezpośrednie wybory prezydentów w największych miastach Polski w 2002 r., „Annales Universitatis Mariae Curie-Skłodowska”, Sektio K, vol. XI.

Stelmach S. (2010), Dlugowieczni w samorzadach, https://www.rp.pl/artykul/455069-Dlugowieczniw-samorzadach.html, 6 IV 2010.

joko/ kon/ rpo/ kow/ ban/ ali/ jsz/ bls/ ren/ sibi/ epr/ mmd/ rau/ par/ bk/, Samorzadowcy z dlugim stażem o swojej recepcie na sukces, https://www.money.pl/archiwum/wiadomosci agencyjne/pap/ artykul/samorzadowcy;z;dlugim;stazem;o;swojej;recepcie;na;sukces,86,0,675158.html, 14 IX 2010.

Szczepański D. (2015), Ruch miejski smart city na Podkarpaciu. Nowoczesna inicjatywa społeczna czy działalność partyjna pod zmienionym szyldem, ZNUS „Acta Politica”, nr 33.

Szczepański D. (2016), Upartyjnienie versus personalizacja jako czynniki determinujace zachowania wyborcze w krajowych elekcjach w 2015 roku, „Political Preferences”, nr 12.

Ustawa z dnia 5 stycznia 2011 r. Kodeks wyborczy, Dz. U. 2018, poz. 75.

Webb P., Poguntke T. (2013), The presidentialisation of politics thesis defended, „Parliamentary Affairs", nr 66 (3).

The longer this „non-partisan”? Elections of leaders of Polish major cities in the 2002-2018

\section{Summary}

The subject of the research undertaken in the article are the competitions (in the years 2002-2018) for the position of the mayor of the city in 19. Polish cities. The main goal was to find answer for the 
question: was party affiliation promoted incumbents or rather favored the alternation of power in the cities. The position of political parties was examined on the basis of two criteria. The first one was the number of incumbents affiliated with political parties. Another was the number of participants in the mayor's competitions who obtained the second result after the winner. In the examined cities 60 . reelection cases were recorded - in the majority there were nonpartisan incumbents. In 16 cases of power alternation, however, the candidates of political parties dominated. In the years 2002-2018 in all cities there were exactly 95 elections ( 19 cities x 5 elections) - in as many as 74 of them the main rivals of the winners were the candidates of political parties. The research has shown that the multi-years incumbency were favored outside the party, and - on the other hand - the political parties played a greater role in the changes of the mayors of cities.

Key words: reelections of mayor of city, incumbents, political parties, as like nonpartisan actor, personalization of local elections 